\title{
Public Transport Subsidies and Affordability in Mumbai, India
}

\author{
Maureen Cropper ${ }^{1,2}$ and Soma Bhattacharya ${ }^{1}$ \\ ${ }^{1}$ University of Maryland, College Park, MD 20742, USA \\ ${ }^{2}$ Resources for the Future, Washington, DC 20036, USA \\ Correspondence should be addressed to Maureen Cropper, mcropper@umd.edu
}

Received 24 March 2012; Revised 22 July 2012; Accepted 4 September 2012

Academic Editor: David Wong

Copyright (C) 2012 M. Cropper and S. Bhattacharya. This is an open access article distributed under the Creative Commons Attribution License, which permits unrestricted use, distribution, and reproduction in any medium, provided the original work is properly cited.

This paper describes the role of public transport and incidence of transport subsidies in Mumbai, India, where public transport is used for over $75 \%$ of all motorized trips. On average, expenditure on public transit constitutes a larger share of income for the poor than for the middle class. However, a larger fraction of transit users are middle class. In terms of incidence, the poorest $27 \%$ of the population receives only $19 \%$ of bus subsidies and $15.5 \%$ of rail subsidies. One-quarter of these households do not use rail, and $10 \%$ do not use bus, implying that they receive no transit subsidies. Improving the welfare of the poor through demandside subsidies or cash transfer is, however, difficult. We therefore examine the optimal level of transit subsidies, based solely on distributional considerations.

\section{Introduction}

Subsidies to public transport are common in developing countries and are often justified on the grounds that they make transport affordable, rather than on efficiency grounds. Given this justification, it is of interest to know how the benefits from transport subsidies are distributed. As previous analyses have noted $[1,2]$, supply-side subsidies—subsidies which make up revenue losses and thus reduce fares by a constant percent-are likely to be regressive or neutral. Although the purpose of such subsidies is not primarily to redistribute income, their incidence should be of interest to policymakers. Policymakers should also care about the level of such subsidies: if the purpose of subsidies is to make transport affordable, the optimal level of subsidy will depend on the source of funds for the subsidy, on the income elasticity of public transport, and on the welfare weights that the policymaker attaches to different income classes.

We examine both issues for Mumbai, India. Mumbai has an extensive rail and bus system, and public transport is used for over $75 \%$ of all motorized trips in Greater Mumbai. Both rail and bus fares in Mumbai are subsidized: BEST, which operates public buses in Mumbai, is also an electric utility and subsidizes bus fares from electricity revenues. The Central and Western Railways (part of Indian Railways) operate rail services in suburban Mumbai. Although rail fares cover operating costs, they do not fully cover capital costs; hence, there is an implicit supply-side subsidy to rail fares in Mumbai.

We analyze the incidence of these subsidies using data from a survey of households in Greater Mumbai that we conducted in the winter of 2003-2004. ${ }^{1}$ In Mumbai, as in many other cities, the middle class is more likely to use public transport for travel than the poor. The poor, however, also use public transit, and their expenditure on public transit constitutes, on average, a larger share of their income than it does for the middle class. We use the expenditure data from our survey to analyze the incidence of public transit subsidies in Mumbai. Although 90\% of the poor receive bus subsidies and three-quarters receive rail subsidies, an even higher percent of the nonpoor receive subsidies, implying that subsidies are not well targeted. We do not, however, believe that a program of cash transfers to the poor to cover transport costs, or an employer-based system of transport passes, would be easy to implement in Mumbai.

Given that supply-side subsidies are the most feasible option, we ask how large these subsidies should be, on distributional grounds. ${ }^{2}$ Dodgson and Topham [3] determine whether it is appropriate to reduce the price of public transit based on the source of funds for the subsidy and 
on the welfare weights that a policymaker attaches to the marginal utility of income. If, for example, the revenue for transit subsidies comes from property taxes and the income elasticity of demand for housing is greater than the income elasticity of demand for transit, it is possible that a reduction in the transit fare is optimal. This becomes more likely the faster the social marginal utility of income rises as income declines. Applying their reasoning to bus subsidies in Mumbai suggests that a further decrease in fares might be warranted.

The remainder of the paper is organized as follows. The second section presents an overview of Greater Mumbai and describes the travel patterns of households based on our survey data. In Section 3, we present information on household expenditure on transport and discuss the structure of rail and bus fares. Section 4 evaluates the magnitude and incidence of transit subsidies. The optimal transit subsidy is discussed in Section 5. Section 6 concludes.

\section{Background: Travel Patterns in Mumbai}

Greater Mumbai, the focus of this study, constitutes the core of the Mumbai Metropolitan Region (MMR). Greater Mumbai, with a population of 12.5 million people in 2011, is one of the most densely populated cities in the world. The city faces enormous challenges with shortages of land, housing, infrastructure, and social services that have not kept up with the growing demands of the city. An estimated 50 percent of the city's population lives in slums.

Mumbai's public transport system consists of a suburban rail system and public bus system, as well as private taxis and autorickshaws. The suburban rail network carries over 7.33 million passengers every day. Public buses operated by the Brihanmumbai Electric Supply and Transport Undertaking (BEST) carry over 3.67 million passengers each day [4].

To better understand travel patterns, we conducted a survey of 5,000 randomly sampled households in the Greater Mumbai region in the winter of $2004 .^{3}$ The goal of the survey was to characterize the travel patterns of poor and nonpoor households, to estimate the time and money costs of travel and to evaluate the impact of various transport policies. A questionnaire was administered to each household, and travel diaries were completed by the head of household, a randomly chosen adult over 21 , and a randomly chosen household member between 16 and 21 .

In Mumbai, as in other developing country cities, the journey to work constitutes the largest fraction of household trips in terms of distance traveled, accounting for approximately two-thirds of miles traveled. Table 1 describes the main mode used on a typical commute trip. The main mode is defined to be the mode that takes the longest time, with the exception of "on foot" and "bicycle," which are counted as the main mode only if they are the only mode used on the trip. Table 1 indicates that $45 \%$ of commuters walk to work, $22 \%$ rely on rail or rail and bus as their main mode, and $22 \%$ ride a bus to work - either as a main mode (14\%) or to connect with rail. ${ }^{4}$ The modal shares for private vehicles are much smaller-approximately 3\% each for bicycle and
TABLE 1: Main mode to work.

\begin{tabular}{lcc}
\hline $\begin{array}{l}\text { Main transport } \\
\text { mode }\end{array}$ & $\begin{array}{c}\text { Percentage of } \\
\text { all households }\end{array}$ & $\begin{array}{c}\text { Percentage of households } \\
\text { with income }<\text { Rs. 5k }\end{array}$ \\
\hline On foot & 45.3 & 62.7 \\
Bicycle & 3.0 & 6.0 \\
Rail & 14.2 & 10.0 \\
Public bus & 13.9 & 11.3 \\
Rail and bus & 7.9 & 5.0 \\
Autorickshaw & 1.7 & 1.3 \\
Taxi & 0.1 & 0.0 \\
Own two wheelers & 8.4 & 0.8 \\
Own car & 2.6 & 0.1 \\
Other's car & 0.2 & 0.2 \\
Other & 2.6 & 2.8 \\
Sample size & $\mathbf{5 8 4 5}$ & $\mathbf{1 2 7 0}$ \\
\hline
\end{tabular}

car and $8.4 \%$ for two wheelers. ${ }^{5}$ Of commuters who take motorized transport to work, $70 \%$ take either rail or bus or both.

The respective modal shares are somewhat different for the poorest income group in the survey, defined as households with a monthly income below Rs. 5,000: 63\% of the workers in these households walk to work, $6 \%$ ride a bicycle, $15 \%$ take the train (or train and bus), and $16 \%$ ride the bus (either alone or in conjunction with the train). However, of those workers who use motorized transport, $84 \%$ take either rail or bus or both.

Table 2 provides modal splits for all adult trips, by trip purpose. ${ }^{6}$ The modal shares of work trips differ slightly from Table 1, as they reflect the work trips of all adults in the household, based on travel diaries. The modal shares for other trips reflect the travel behavior of adults 16 years of age and older.

The shares of rail and bus in total trips remain high. Train is used for $15 \%$ of school trips (for students 16 years of age and older) and also for social visits. Public bus has a significant modal share for school trips and also for personal business, entertainment, and social visits.

\section{Affordability of Transport}

3.1. Household Expenditure on Transport. The fact that a high percent of trips_-including work trips_-are made on foot does not imply that expenditures on transport are low, even for households where the primary earner walks to work (see Table 3). As Table 3 indicates, in poor households where the principal wage earner walks to work, $12.5 \%$ of family income is spent on transport. The figure is even higher in households where the main earner takes the bus or train to work: in households where the main earner takes the train to work $16.8 \%$ of household income is spent on transportation; the percent spent on transport is $19.4 \%$ for households where the main earner takes the bus to work.

Table 4 shows mean total household expenditure on transport, by category of expenditure. Average household 
TABle 2: Percentage distribution of trips by mode, for each trip purpose.

\begin{tabular}{|c|c|c|c|c|c|c|}
\hline Main transport mode & Work & School & Entertainment & Health care & Personal business & Household average \\
\hline On foot and bicycle & 48.6 & 55.9 & 51.6 & 67.7 & 49.1 & 54.7 \\
\hline Rail & 20.9 & 15.3 & 3.5 & 1.2 & 13.2 & 15.4 \\
\hline Public bus & 15.1 & 22.3 & 16.0 & 12.8 & 18.3 & 14.6 \\
\hline Autorickshaw/taxi & 2.4 & 3.4 & 10.5 & 16.3 & 7.5 & 5.4 \\
\hline Private motorized transport & 12.2 & 2.7 & 18.5 & 2 & 12 & 9.4 \\
\hline Other & 0.8 & 0.3 & 0 & 0 & 0 & 0.5 \\
\hline Total & 100 & 100 & 100 & 100 & 100 & 100 \\
\hline
\end{tabular}

TABle 3: Percent of household expenditure on transportation by income and commute mode of principal earner.

\begin{tabular}{lccccc}
\hline & Walk & Rail & Bus & MTW & Car \\
\hline$<5 \mathrm{k}$ & 12.5 & 16.8 & 19.4 & 28.5 & NA \\
$5-7.5 \mathrm{k}$ & 8.6 & 9.3 & 9.9 & 19.8 & NA \\
$7.5-10 \mathrm{k}$ & 7.8 & 8.3 & 8.7 & 16.0 & NA \\
$10-20 \mathrm{k}$ & 7.6 & 9.0 & 8.4 & 14.4 & 20.0 \\
$>20 \mathrm{k}$ & 7.8 & 6.8 & 5.8 & 11.6 & 14.2 \\
\hline
\end{tabular}

expenditure on rail increases with income as do average expenditures on buses - until the highest income category, when it decreases slightly. The percent of income spent on public transport is, however, highest for the lowest income group.

The numbers in Table 4 foreshadow some results regarding the incidence of transit subsidies. As long as the transit subsidy is a constant percentage of the fare for all income groups, the subsidy in Rs. will increase with household expenditure on transit. Hence, transit subsidies in Rs. will increase with income for rail and also for bus (up to the highest income group). The transit subsidy as a percent of income will, however, be highest for the lowest income group, which spends the highest proportion of income on transit. This is clearly indicated in Table 4 which shows that of all income groups the poor spend the highest percent of their income on bus $(6 \%)$ and on rail (3.6\%).

3.2. Fare Structure. The fact that all but the highest income households spend more per month on bus than on rail (see Table 4) reflects the fact that bus fares are higher, per kilometer traveled, than rail fares. At the time of our survey, a person commuting $15 \mathrm{~km}$ each way to work by bus paid a fare of Rs. 18 per day or Rs. 450 per month, assuming 25 workdays per month. A person commuting $15 \mathrm{~km}$ each way to work by rail paid Rs. 75 for a monthly pass-one-sixth the cost of the bus fare. ${ }^{7}$ Bus fares, per $\mathrm{km}$, remain higher than rail fares today, although monthly bus passes are now available.

\section{Magnitude and Incidence of Transit Subsidies}

4.1. Magnitude of Supply-Side Subsidies. Supply-side subsidies, defined as (costs/revenues)-1, are much greater for public buses than for rail. The Transport Division of BEST has historically operated at a loss. During the years 2008/092010/11, the implicit subsidy to bus fares has ranged from $36 \%$ to $54 \%$, averaging $45 \%$. Parts of BEST's transport losses are covered by the profits made by its Electricity Supply Division. Over the past 3 years slightly less than half of the deficit from BEST's bus division has been covered by profits from its electricity supply division, with the remainder made up by government subsidies.

The picture is quite different for the suburban rail system. In 2005-2006, the most recent year for which we have data, revenues covered operating costs but not depreciation. A $1.2 \%$ increase in fares would have been required to cover total costs. The ratio of depreciation to operating costs $(0.078)$ is, however, much lower than the ratio for other rail services around the world, suggesting that reported depreciation understates economic depreciation and hence the subsidy implicit in rail fares [5].

4.2. Incidence of Bus and Rail Subsidies. Because the bus and rail subsidies are a percent of fares, the share of each subsidy going to income group $i$ equals the share of income group $i$ 's expenditure on bus (rail) in total expenditure on bus (rail) and is thus independent of the percent of the fare that is subsidized. Formally,

$$
S_{i j}=\frac{x_{i j} \cdot n_{i}}{\sum_{i} x_{i j} \cdot n_{i}}
$$

where $S_{i j}$ is the share of total subsidy accruing to income group $i$ from travel mode $j, x_{i j}$ is the average monthly expenditure by a household belonging to income group $i$ for travel mode $j$, and $n_{i}$ is the fraction of households in income group $i$. The incidence figures in Table 5 thus apply to any level of bus and rail subsidies that are a percent of the fare.

An equal distribution of subsidy benefits implies that the percentage of subsidy benefit received by an income category equals its share in the population. Our findings indicate that while the poorest households constitute 27 percent of total households in the sample, they receive only 19 and 15.5 percent, respectively, of bus and rail subsidies. The wealthiest households, who constitute less than 6 percent of the total sample, receive bus subsidies that are about 30 percent larger than their equal share, and about twice the rail subsidy benefits than they would receive under a uniform distribution of the subsidy across income groups. The middle income group, earning 7,500-10,000 Rs. per month receives 
TABLE 4: Mean monthly household expenditure (Rs.) on transportation and percent of income spent on transit, by income group.

\begin{tabular}{lcccccc}
\hline & $<5 \mathrm{k}$ & $5 \mathrm{k}-7.5 \mathrm{k}$ & $7.5 \mathrm{k}-10 \mathrm{k}$ & $10 \mathrm{k}-20 \mathrm{k}$ & $>20 \mathrm{k}$ & Household average \\
\hline Bus & 151 & 195 & 221 & 286 & 275 & 210 \\
Rail & 89 & 124 & 165 & 227 & 296 & 152 \\
Taxi & 91 & 121 & 165 & 287 & 397 & 169 \\
School bus & 3 & 5 & 13 & 50 & 59 & 18 \\
Fuel & 59 & 160 & 200 & 589 & 1545 & 301 \\
Motorized and nonmotorized vehicle maintenance & 7 & 33 & 41 & 98 & 307 & 56 \\
\hline Total transportation expenditure & 400 & 638 & 805 & 1537 & 2879 & 906 \\
\hline Share of income (bus expenditure) & $\mathbf{6 . 0} \%$ & $\mathbf{3 . 1} \%$ & $\mathbf{2 . 5} \%$ & $\mathbf{1 . 9} \%$ & $\mathbf{1 . 1} \%$ & $\mathbf{2 . 5} \%$ \\
Share of income (rail expenditure) & $\mathbf{3 . 6} \%$ & $\mathbf{2 . 0} \%$ & $\mathbf{1 . 9} \%$ & $\mathbf{1 . 5} \%$ & $\mathbf{1 . 2} \%$ & $\mathbf{1 . 8} \%$ \\
Share of income (total transportation expenditure) & $\mathbf{1 6 . 0} \%$ & $\mathbf{1 0 . 2} \%$ & $\mathbf{9 . 2} \%$ & $\mathbf{1 0 . 2} \%$ & $\mathbf{1 1 . 5} \%$ & $\mathbf{1 0 . 7} \%$ \\
\hline
\end{tabular}

TABLE 5: Incidence of bus and rail subsidies, by income group.

\begin{tabular}{lccccc}
\hline $\begin{array}{l}\text { Income } \\
\text { group }\end{array}$ & $\begin{array}{c}\text { Percent of } \\
\text { sample }\end{array}$ & \multicolumn{2}{c}{\begin{tabular}{l}
\multicolumn{2}{c}{ Percent of total } \\
subsidy benefits
\end{tabular}} & \multicolumn{2}{c}{$\begin{array}{l}\text { Percent of } \\
\text { households who } \\
\text { receive subsidy }\end{array}$} \\
& & Bus & Rail & Bus & Rail \\
\hline$<5 \mathrm{~K}$ & 26.6 & 19.1 & 15.5 & 90.0 & 73.9 \\
$5001-7500$ & 27.8 & 25.8 & 22.5 & 93.6 & 83.2 \\
$7501-10000$ & 21.9 & 23.1 & 23.8 & 94.3 & 90.8 \\
$10001-20000$ & 17.8 & 24.2 & 26.5 & 92.3 & 87.6 \\
$>20 \mathrm{~K}$ & 5.9 & 7.8 & 11.6 & 81.8 & 79.4 \\
\hline
\end{tabular}

TABLE 6: Errors of inclusion and exclusion of subsidy.

\begin{tabular}{lcc}
\hline Percentage of households & Poor $(<5 \mathrm{~K})$ & Nonpoor \\
\hline Receiving bus subsidy & 90.00 & 92.55 \\
Not receiving bus subsidy & 10.00 & 7.45 \\
Receiving rail subsidy & 73.94 & 86.23 \\
Not receiving rail subsidy & 26.06 & 13.77 \\
\hline
\end{tabular}

subsidy benefits from both bus and rail in roughly equal proportion to their share in the population.

If subsidy benefits should be targeted at the poor, then the percentage of the poor not receiving subsidy benefits is an error of exclusion [6], and the percentage of nonpoor receiving subsidy benefits would constitute errors of inclusion. For simplicity of calculation, we assume here that all users of public bus and rail receive subsidy benefits. Table 6 shows the errors of inclusion and exclusion for both the rail and bus subsidies. Errors of exclusion are 10 and 26 percent for bus and rail, respectively, while errors of inclusion are 93 and 86 percent for bus and rail, respectively.

In Mumbai, the errors of exclusion for the poor are higher for rail than bus. This reflects the fact that a larger fraction of persons in the lowest-income group do not use rail in spite of lower fares for rail. The low usage of rail by the poorest-income group is due to the fact that households in the lowest-income group live closer to their work than persons in the higher-income groups. For all income groups, the percent of commuters using rail increases with commute distance. But commute distances increase

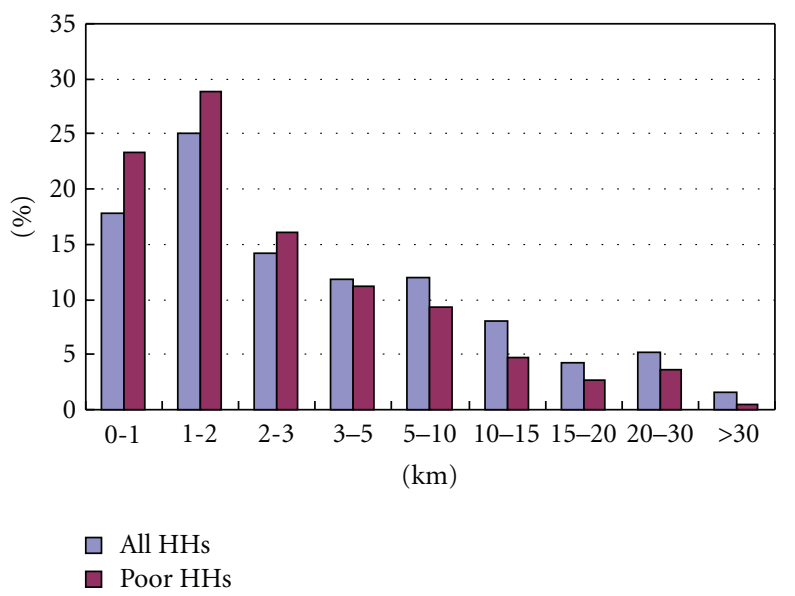

FIGURE 1: Distribution of one-way commute distances.

with income. Figure 1 shows the distribution of one-way commute distances for poor workers and for all workers. As Figure 1 illustrates, the distribution of commute distances for workers in the $<5 \mathrm{~K}$ income group lies to the left of the distribution of commute distances for workers in all households (see Figure 1), implying shorter commutes for the poor. Eighty percent of the poor live $5 \mathrm{~km}$ or closer to their work. This may reflect the fact that it is easier for these workers to find jobs close to home and/or the fact that it is more expensive to live near railway stations, that is, that proximity to rail is capitalized into land values.

What is perhaps more troubling from a targeting perspective is the fact that a high percent of subsidies go to the nonpoor (i.e., that errors of exclusion are high). This could be reduced by providing demand-side subsidies, such as those have been instituted in Brazil, or by making direct cash transfers to the poor; however, both options would be difficult to implement in Mumbai. In Brazil, under the Vale Transporte scheme, employers provide transit passes to workers, which are partially subsidized by government revenues. Estupiñán et al. [1] note that the passes are often sold at a discount in the black market, with workers carpooling or walking to work. They suggest that a direct cash transfer would be preferable. There is no direct cash 
transfer scheme for the poor in Mumbai, and employerprovided transit passes would be difficult to implement in a city with a high percentage of employment in the informal sector. Given these difficulties, supply-side subsidies appear to be the most feasible method of subsidizing public transit in Mumbai. We therefore ask whether current subsidies should be increased, based on distributional grounds.

\section{Optimal Distributional Transit Subsidies}

Dodgson and Topham [3] derive conditions under which a reduction in the price of public transit would be welfare enhancing, given the distribution of income in a city, the income elasticity of demand for public transport, and assumptions about the sources of revenues used to fund the subsidy. In the case they consider, transit fares are subsidized out of property taxes. The goal of a planner, who must fund a fraction $(1-g)$ of the reduction in transit fares from property tax revenues, is to maximize the welfare of households in the city, who differ in income $(m)$ but have identical preferences for goods and services. ${ }^{8}$ In maximizing welfare, the planner attaches a weight $\beta^{\prime}(m)$ to the marginal utility of income received by a household with income $m$.

As shown in the Appendix, the condition for a reduction in the price of transit to be welfare maximizing is for

$$
\frac{\Delta}{\left[1+\tau_{1} \eta_{1}\right]}>\frac{(1-g)}{\left[1+\tau_{0} \eta_{0}\right]},
$$

where $\Delta$ represents the ratio of the "distributional characteristic" of public transit to the taxed good, $\tau_{i}$ denotes the tax or subsidy rate for good $i$, as a proportion of the price faced by the consumer, and $\eta_{i}$ is the price elasticity of demand for good $i$. We use the subscript " 0 " to denote the taxed good and " 1 " to denote public transit. ${ }^{9} \Delta$, which represents the ratio of welfare-weighted demand for transit relative to the welfare-weighted demand for the taxed good, will be $>1$ if the income elasticity of the taxed good is greater than the income elasticity of demand for public transit.

Equation (2) says that a transit subsidy is justified if the marginal cost of public funds (the RHS of (2)) is less than the distributional benefits of the fare reduction (the LHS of (2)). The marginal cost of public funds is smaller, the greater is the fraction of revenue that the city receives from the federal government $(g)$, and the less price elastic is the demand for the taxed good.

The the distributional benefits of lowering transit fares will be greater, the smaller is the current subsidy and the less price elastic is the demand for transit. They also depend crucially on $\Delta$. The standard approach to computing $\Delta$ in the public finance literature [7] is to assume that income, $m$, follows a lognormal distribution, $\beta^{\prime}(m)=m^{-\delta}$, and goods 0 and 1 can be described by isoelastic demand functions. Under these assumptions,

$$
\Delta=\exp \left[\delta \sigma^{2}\left(\theta_{0}-\theta_{1}\right)\right]
$$

where $\sigma^{2}$ is the variance of $\log (m)$, and $\theta_{i}$ is the income elasticity of good $i$. A transit subsidy is thus more likely to be justified: (a) the higher the social inequality parameter $\delta$ (b), the more unequal the distribution of income (the larger is $\sigma^{2}$ ), and (c) the more income elastic is the taxed good relative to public transit.

We now consider the implications of (2) and (3) for bus subsidies in Mumbai. Estimates of the price and income elasticity of demand for bus travel have been estimated by one of us using our Mumbai survey data [8]. Our estimates suggest that $\theta_{1}=0.25$ and $\eta_{1}=-0.42$. In Mumbai, bus subsidies have been at least partially funded out of electricity revenues, since BEST is also an electric utility. Estimates of the price and income elasticity of demand for electricity in India are provided by Gundimeda and Köhlin [9]. Their elasticities for urban areas in India suggest that $\theta_{0}=0.60$ and $\eta_{0}=-0.52$.

Whether an increase in bus subsidies is warranted also depends on the distribution of income in Mumbai and on the income inequality parameter $\delta$. Annez et al. [10] report the mean monthly income in Mumbai to be Rs. 40,000 and the median monthly income to be Rs. $21,000 .^{10}$ Assuming that income is lognormally distributed, this implies that $\sigma^{2}=$ 1.436. The value of $\delta$ is a subject of much debate. One way to interpret $\delta$ is in terms of the maximum sacrifice that a higher-income person should be asked to make to increase the income of a poorer person. If $\delta=1$, then a household with $2 \mathrm{~m}$ of income should be asked to forgo Rs. 2 to provide an additional rupee to a household with $1 \mathrm{~m}$ of income. If $\delta=$ 2 , the higher income household should be asked to forgo Rs. 4 to provide an additional rupee to a household with $1 \mathrm{~m}$ of income. Dodgson and Topham cite values of $\delta=2$ for the UK based on Stern [11]. However, the official value of $\delta$ used by the UK government is 1 [12]. A value of $\delta=1$ implies that $\Delta$ $=1.65$, while a value of $\delta=2$ implies that $\Delta=2.73$.

Our calculations suggest that an increase in bus subsidies might be warranted on distributional grounds. Evaluating the LHS of (2) at the average subsidy of $45 \%$ to bus fares yields an LHS $=1.39$ if $\delta=1$. The RHS depends on how much of the subsidy comes from electricity revenues. Even if all of these subsidies were to come from higher electricity prices, the price of electricity would rise by no more than $20 \%$. This would imply that the RHS of $(2)=1.12$ and, hence, that an increase in bus subsidies is warranted. This conclusion is, of course, heavily dependent on the choice of $\delta$. Our calculations suggest that if $\delta=0.5$, current subsidies are roughly optimal. ${ }^{11}$

\section{Conclusions}

Carruthers et al. [13] report that Mumbai ranks sixth among 27 cities for which they have calculated indices of public transport affordability. That is, Mumbai is the sixth most expensive city. The figures presented in this paper bear this out. Expenditure on transport accounts for $16 \%$ of income in the lowest-income category (<5000 Rs./month), with $10 \%$ of income, on average, spent on bus and rail fares. This percentage, however, is not evenly distributed; it is much higher than $10 \%$ for households in which workers take the bus or train to work and lower for households in which 
the main earner walks to work. Even in these households, however, $12.5 \%$ of income is spent on transportation.

Expenditure on public transport would be even higher if bus fares in Mumbai were not subsidized. Over the period 2008/2009-2010/2011, transport revenues of BEST fell below total costs by an average of $45 \%$. Rail fares, which are much lower than bus fares per $\mathrm{km}$ traveled, officially covered operating costs and almost covered depreciation expenses.

If one asks who benefits from bus subsidies in Mumbai, the answer is clear: households with incomes below Rs. 5,000 per month, who constitute $27 \%$ of the population, receive $19 \%$ of bus subsidies, while households with incomes above Rs. 10,000 per month, who constitute $24 \%$ of the population, receive $31 \%$ of bus subsidies. Ten percent of households in the below Rs. 5,000 group do not use bus services and thus receive no subsidy.

Policymakers concerned about the welfare of the poor might argue that it would be more efficient to provide cash transfers to poor households or, if the goal is to encourage the consumption of transport services, to provide demandside subsidies, as is done in Brazil [1]. Neither option is, however, practical in the case of Mumbai: there is no system of cash transfers to the poor, and demand-side subsidies of the type used in Brazil are difficult when a large portion of the population works in the informal sector. This leads us to examine the optimal supply subsidy to bus fares.

As Dodgson and Topham [3] show, the optimal subsidy on distributional grounds depends on the income elasticity of demand for bus transit, the income elasticity of demand for the good that is taxed to provide the subsidy (in this case, electricity), and the distribution of income in the city in question. It also depends on the welfare weights attached to the marginal utility of income. We have provided rough calculations that suggest that a subsidy to bus fares of $50 \%$ can very likely be justified on distributional grounds.

\section{Appendix}

\section{A. Optimal Distributional Subsidies ${ }^{12}$}

Suppose that a planner can alter the price of public transportation in a city $\left(q_{1}\right)$. A portion $(1-g)$ of the funds for the subsidy must come out of the source of local tax revenue, a tax on good 0 . All households in the city have identical preferences for goods and services but differ in their incomes. Denote the household's indirect utility function $\psi(\mathbf{q}, m)$ where $m$ is income, and $\mathbf{q}$ is the vector of prices for all goods and services. The planner's goal is to maximize the sum of utilities of all households in the city, where $f(m)$ is the probability distribution of income, and $\beta^{\prime}(m)$ is the marginal utility that the planner attaches to an additional unit of income for a household with income $m$. The planner's goal is thus to maximize the social welfare of the population $(N)$ as follows:

$$
N \int \psi(\mathbf{q}, m) \beta^{\prime}(m) f(m) d m
$$

A marginal reduction in the transit fare $\left(q_{1}\right)$ and corresponding increase in the price of the taxed good $\left(q_{0}\right)$ will be optimal if

$$
-\Delta\left[X_{1} d q_{1}\right]>X_{0} d q_{0}
$$

where $X_{i}$ is the aggregate demand for good $i$. Equation (A.2) says that a fare reduction is warranted if the welfare-weighted reduction in revenues $\left(-X_{1} d q_{1}\right)$ exceeds the tax revenues required to fund the subsidy. $\Delta$ represents the ratio of the "distributional characteristic" of public transit to the taxed good and is discussed further below. Totally differentiating the planner's budget constraint, $t_{0} X_{0}=(1-g)\left[C_{1}\left(X_{1}\right)-q_{1} X_{1}\right]$ where $C\left(X_{1}\right)$ is the cost of public transport, yields

$$
-X_{1} d q_{1}(1-g)\left[1+\tau_{1} \eta_{1}\right]=X_{0} d q_{0}\left[1+\tau_{0} \eta_{0}\right],
$$

where $\tau_{i}$ denotes the tax or subsidy rate for good $i$, as a proportion of the price $\left(q_{i}\right)$, and $\eta_{i}$ is the price elasticity of demand for good $i .{ }^{13}$ Substituting (A.3) into (A.2) implies that a transit subsidy is justified if

$$
\frac{\Delta}{\left[1+\tau_{1} \eta_{1}\right]}>\frac{(1-g)}{\left[1+\tau_{0} \eta_{0}\right]} .
$$

To evaluate this condition requires parameterizing $\Delta$. The standard approach in the public finance literature [7] is to assume that income, $m$, follows a lognormal distribution, $\beta^{\prime}(m)=m^{-\delta}$, and goods 0 and 1 can be described by isoelastic demand functions. Under these assumptions,

$$
\Delta=\exp \left[\delta \sigma^{2}\left(\theta_{0}-\theta_{1}\right)\right]
$$

where $\sigma^{2}$ is the variance of $\log (m)$, and $\theta_{i}$ is the income elasticity of good $i$.

\section{Disclosure}

The findings, interpretations, and views expressed in this paper are entirely those of the authors. They do not necessarily represent the views of the World Bank, its Executive Directors, or the countries they represent.

\section{Endnotes}

1. Baker et al. [14] describe the survey design and provide a copy of the questionnaires used.

2. There is also an economic efficiency argument for subsidies to public transport: if it is infeasible to charge private vehicles for the externalities they cause (e.g., congestion, accidents, and pollution), then subsidies to public transit may be justified. Transit subsidies may also be justified by the fact that the marginal cost of providing transit services is less than average cost. Parry and Small [15] calculate these subsidies for London, Los Angeles, and Washington, DC.

3. The survey, funded by the World Bank, was designed and supervised by Judy Baker, Rakhi Basu, Maureen Cropper, and Somik Lal. 
4. In Table 2, these shares, based on travel diaries, are respectively, $46 \%$ walking, $21 \%$ rail, and $15 \%$ bus.

5. The shares based on the travel diaries are 3.5\% for bicycle, $3.2 \%$ for own car, and $8.6 \%$ for own two wheelers.

6. In Table 2, "rail" refers to "rail" and "rail and bus."

7. The cost of travel by rail, per kilometer, is lower than the cost by bus, even if no monthly pass is purchased. See Cropper and Bhattacharya [5] for details.

8. It is assumed that the federal government funds a portion $g$ of the transit subsidy.

9. Note that this implies $\tau_{0}>0$ and $\tau_{1}<0$.

10. The income data in Annez et al. [10] are more detailed than in our survey, which reports only four income categories.

11. If $\delta=0.5$, then a household with $2 \mathrm{~m}$ of income should be asked to forgo Rs. 1.41 to provide an additional rupee to a household with $1 \mathrm{~m}$ of income.

12. This Appendix follows Dodgson and Topham [3], with simplifying assumptions.

13. In other words, $q_{i} \equiv p_{i}+\tau_{i}$ where $p_{i}$ is the producer price of $\operatorname{good} i\left[=C\left(q_{1}\right)\right.$ for transit $]$.

\section{References}

[1] N. Estupiñán, A. Gómez-Lobo, R. Muñoz-Raskin, and T. Serebrisky, "Affordability and subsidies in public urban transport: what do we mean? What can be done?" mimeo, World Bank, 2008.

[2] A. Gómez-Lobo, "Public transport affordability and subsidy policies, a case study of Santiago, Chile," mimeo, World Bank, 2007.

[3] J. S. Dodgson and N. Topham, "Benefit-cost rules for urban transit subsidies. An integration of allocational, distributional and public finance issues," Journal of Transport Economics \& Policy, vol. 21, no. 1, pp. 57-72, 1987.

[4] MMRDA, http://www.mmrdamumbai.org/showProject.jsp? srv=AhP1bS4i337HeA, 2012.

[5] M. Cropper and S. Bhattacharya, "Public transport subsidies and affordability in Mumbai, India," Policy Research Working Paper Series 4395, The World Bank, Washington, DC, USA, 2007.

[6] V. Foster, "Toward a social policy for argentina's infrastructure sectors. Evaluating the past, exploring the future," Policy Research Working Paper Series 3422, The World Bank, Washington, DC, USA, 2004.

[7] M. S. Feldstein, "Distributional equity and the optimal structure of public prices," American Economic Review, vol. 62, pp. 32-36, 1972.

[8] A. Takeuchi, M. Cropper, and A. Bento, "The impact of policies to control motor vehicle emissions in Mumbai, India," Journal of Regional Science, vol. 47, no. 1, pp. 27-46, 2007.

[9] H. Gundimeda and G. Köhlin, "Fuel demand elasticities for energy and environmental policies: Indian sample survey evidence," Energy Economics, vol. 30, no. 2, pp. 517-546, 2008.

[10] P. C. Annez, A. Bertaud, B. Patel, and V. K. Pathak, "Working with the market: a new approach to reducing urban slums in India," Policy Research Working Paper Series 5475, The World Bank, Washington, DC, USA, 2010.
[11] N. H. Stern, "The Marginal Value of Income," in Studies in Modern Economic Analysis, M. Artis and A. R. Nobay, Eds., Blackwell, Oxford, UK, 1977.

[12] H. M. Treasury, "Green Book," http://www.hm-treasury.gov. uk/data_greenbook_index.htm, 2003.

[13] R. Carruthers, M. Dick, and A. Saurkar, "Affordability of public transport in developing countries," Transport Paper 3, Transport Sector Board, The World Bank, Washington, DC, USA, 2005.

[14] J. Baker, R. Basu, M. Cropper, S. Lall, and A. Takeuchi, "Urban poverty and transport: the case of Mumbai," Policy Research Working Paper Series 3693, The World Bank, Washington, DC, USA, 2005.

[15] I. W. H. Parry and K. A. Small, "Should urban transit subsidies be reduced?" American Economic Review, vol. 99, no. 3, pp. 700-724, 2009. 


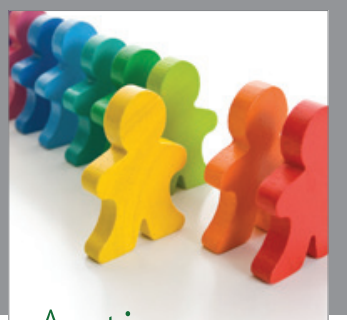

Autism

Research and Treatment
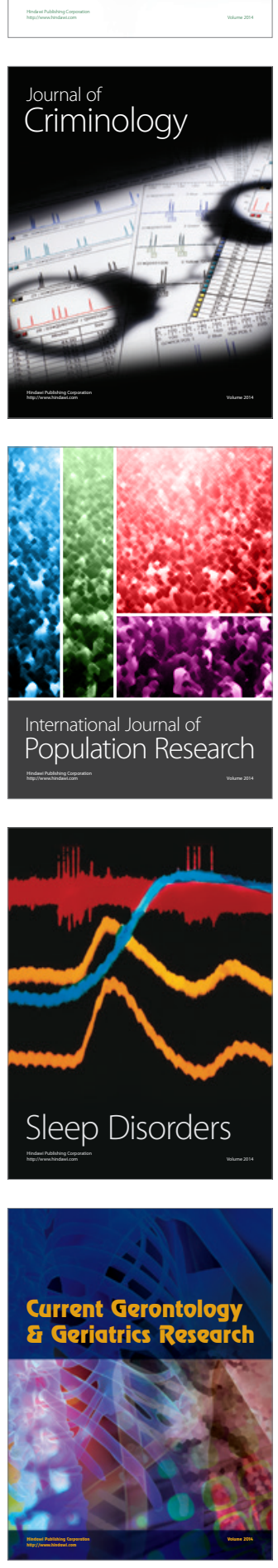
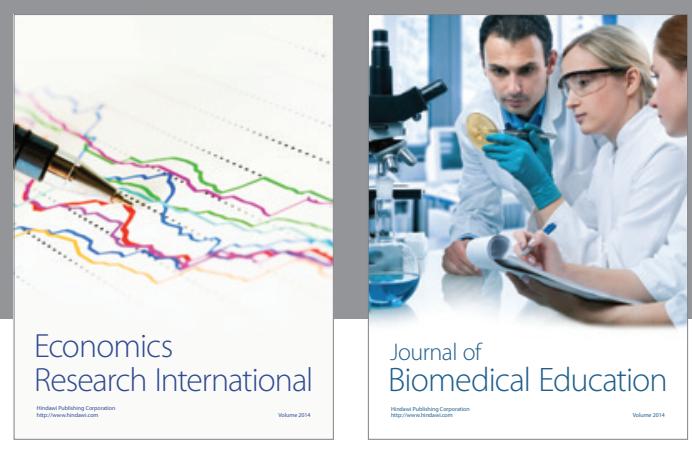

Journal of

Biomedical Education

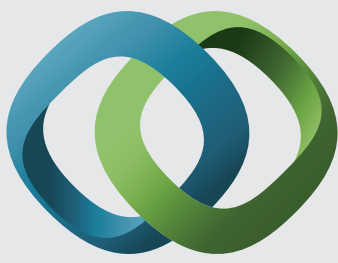

\section{Hindawi}

Submit your manuscripts at

http://www.hindawi.com
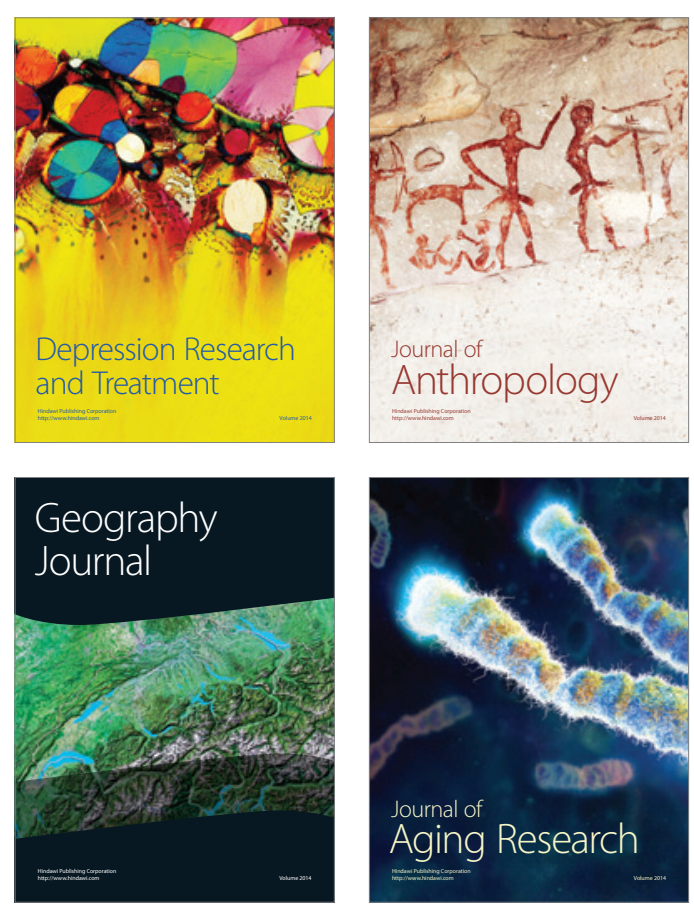

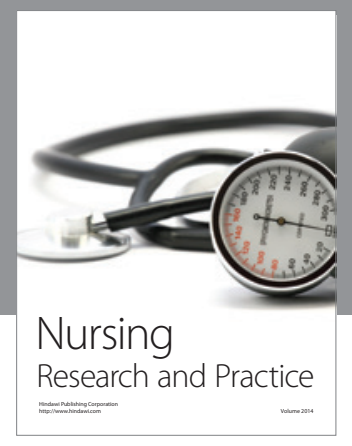

Nursing

Research and Practice

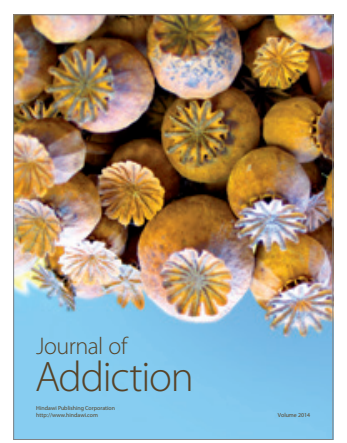

Child Development

Research

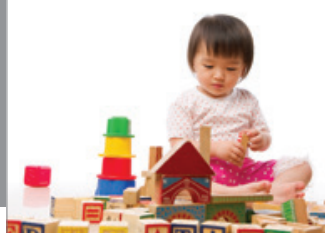

迥
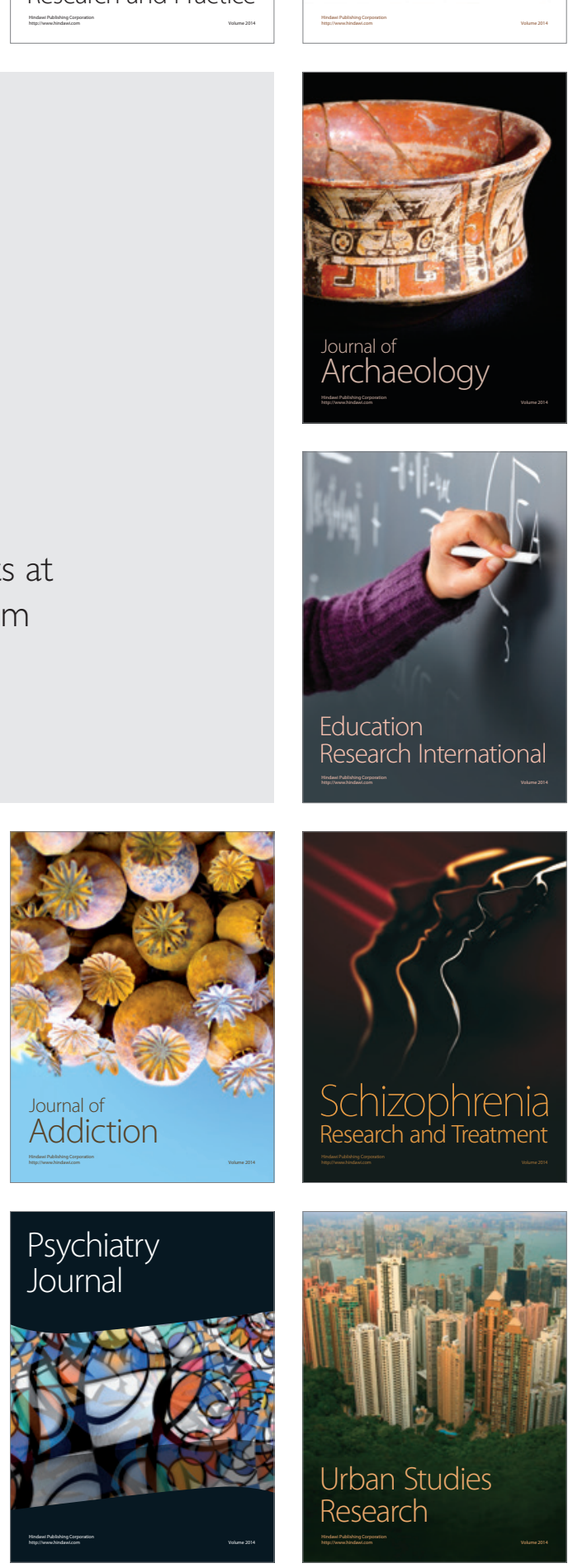